\title{
Phospholipid Ether-drug Conjugate CLR
}

\section{1}

National Cancer Institute

\section{Source}

National Cancer Institute. Phospholipid Ether-drug Conjugate CLR 131. NCI Thesaurus.

Code $C 84879$.

A radiopharmaceutical composed of a mixture of proprietary phospholipid ethers (CLR 1404) that are covalently linked to the cytotoxic radioisotope iodine I 131 (iodine-131), with potential antineoplastic activity. Upon administration of CLR 131, the phospholipid ether (PLE) moiety is selectively taken up by lipid raft microdomains expressed on tumor cells and accumulates in the cytoplasm of tumor cells;. CLR 131 is not taken up by normal, healthy cells. This delivers cytotoxic iodine I 131 directly to and induces cell death in tumor cells. PLEs allows for targeted delivery of the radioisotope. 